\title{
YALE
}
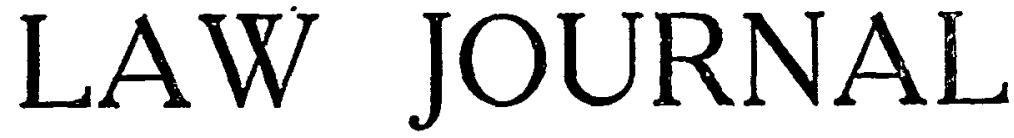

Vol. XXXV

NOVEMBER, 1925

No. 1

\section{THE JURISDICTION OF THE SUPREME COURT UNDER THE ACT OF FEBRUARY 13, 1925}

\section{WILLIAII HOWARD TAFT}

I am asked by the Editor of this Journal to say something about the recent Act of Congress of February 13th last, amending the statutes controlling the appellate jurisdiction of the Supreme Court and of the Circuit Courts of Appeals of the United States. Satisfactory expositions of the Act, with detailed reference to its sections, have been given by Mr. Charles W. Bunn in the Minnesota Law Review, ${ }^{1}$ and in the West Publishing Company's Docliet for April, 1925; by MIr. Paxton Elair in the Columbia Law Review in the April number of this year; ; by U. S. District Judge Trieber, of Arkansas, in an address to the Bar Association of that State; and by others. I shall only attempt to point out its broad purpose and its general effect, without section citation.

At the centenary celebration of the launching of the Federal Constitution in Philadelphia, the addresses of the Justices of the Supreme Court and of the distinguished members of the Ear contained urgent appeals to Congress to relieve the Court, which was then considerably more than three years behind.

Congress sought to remove the congestion by the Act of MIarch 3d, 1891.3 It created nine Circuit Courts of Appeals as intermediate courts of review. The parliamentary situation with respect to the bill had been such that if a measure of that lind was to pass in the last days of the 50th Congress, it had to pass exactly as it was reported by the Senate Judiciary Committee. It was not, therefore, subjected to as full and free discussion as was desirable, and was not freed from gaps and obscurities which more careful consideration would have avoided. The Supreme Court in its interpretation has had difficulty in clarifying it.

In the Act of 1891, Congress for the first time conferred upon the Supreme Court, in extensive classes of litigation, discretion

\footnotetext{
1 (1925) 9 IITNN. L. REV. 309.

2 (1925) 25 Cor. L. REv. 393.

326 StAT. AT. L. 826.
} 
to decline to review cases if they did not seem to the Court to be worthy of further review. In this discretionary jurisdiction the most numerous class of cases was of those which depended upon the diverse citizenship of the parties as the basis of federal jurisdiction. Patent cases, copyright cases, Federal trade-mark cases, admiralty cases, revenue cases, criminal cases, and most bankruptcy cases were similarly dealt with either in the original Act or by amendments. A review in them was given in the nine Circuit Courts of Appeals. Their disposition by those courts was thus made final, unless they were removed by the discretionary writ of certiorari to the Supreme Court.

The Circuit Courts of Appeals worked well. Speaking generally, they were always abreast of their dockets, and their activity soon removed the "hump" in the docket of the Supreme Court. After thirty-five years, however, that Court's business had again grown beyond its capacity, and a hearing could not be had for cases not advanced out of their order until more than a year after their filing. The members of the Court, afraid that the docket might become more congested, brought the matter to the attention of the Judiciary Committees of both Houses of Congress, and it was there suggested that the Court prepare a bill to help matters. A committee of the Court was appointed, of which Mr. Justice Day was Chairman, Mr. Justice Van Devanter and Mr. Justice McReynolds were members, and the Chief Justice acted ex officio. Upon the retirement of Mr. Justice Day, Mr. Justice Van Devanter became the Chairman of the Committee. In the pressure of the regular judicial work, the bill was not fully and satisfactorily formulated until the last session of the first Congress in the Harding Administration. Its legislative consideration was delayed by measures regarded as more pressing until the last session of the last Congress.

The chief agency employed in the new Act to accomplish its purpose is the enlargement of the classes of cases which must stand the preliminary test of an application for a writ of certiorari before they can be reviewed by the Court, i. e. by transferring more cases from the obligatory to the discretionary jurisdiction than as provided in the Act of 1891 and its amendments.

The sound theory of that Act and of the new Act is that litigants have their rights sufficiently protected by a hearing or trial in the courts of first instance, and by one review in an immediate appellate Federal court. The function of the Supreme Court is conceived to be, not the remedying of a particular litigant's wrong, but the consideration of cases whose decision involves principles, the application of which are of wide public or governmental interest, and which should be authoritatively declared by the final court. Such cases should include issues of the Federal constitutional validity of statutes, Federal and State, genuine issues of 
constitutional right of individuals, the interpretation of Federal statutes when it will affect large classes of people, questions of Federal jurisdiction, and sometimes doubtful questions of general law of such wide application that the Supreme Court may help to remove the doubt. Where there is a conflict of opinion between intermediate appellate courts in the different Cireuits or between the federal intermediate appellate courts and the Supreme Courts of the States, the public interest certainly requires that the Supreme Court hear the cases, if its decision will remove the conflict.

The Court has thought it wise to indicate the lines along which its discretion will be exercised in granting certioraris, in Par. 5 of Rule 35 of the new Rules adopted by the Court in June last, to square with the new Act.*

The number of applications for certiorari is much greater than it should be. It is natural, I suppose, that a defeated party should seek to exhaust every remedy in a case of great personal importance and should pay little heed to the indispensable conditions of our granting the writ. But counsel are charged with a greater sense of responsibility in the matter. They should know whether cases involve issues putting them within the class in which certiorari is possible or probable. If not, it is their duty to the Court to save it from useless labor, and to their clients to save them from the heavy and useless expense of getting the record and preparing and printing the petition and brief. Easily one-half of the certiorari applications now presented have no justification at all. It sometimes happens, I hope

\footnotetext{
"Par. 5 is as follows:
}

"5. A review on writ of certiorari is not a matter of right, but of sound judicial discretion, and will be granted only where there are special and important reasons therefor. The following, while neither controlling nor fully measuring the court's discretion, indicate the character of reasons which will be considered:

(a) Where a state court has decided a federal question of substance not theretofore determined by this court, or has decided it in a way probably not in accord with applicable decisions of this court.

(b) Where a circuit court of appeals has rendered a decision in conflict with the decision of another circuit court of appeals on the same matter; or has decided an important question of loeal law in a way probably in conflict with applicable local decisions; or has deeided an important question of general law in a way probably untenable or in conflict with the weight of authority; or has decided an important question of federal law which has not been, but should be, settled by this court; or has decided a federal question in a way probably in conflict with applicable decisions of this court; or has so far departed from the accepted and usual course of judicial proceedings, or so far sanctionel such a departure by a lower court, as to call for an exercise of this court's power of supervision.

(c) Where the Court of Appeals of the District of Columbia has decided a question of general importance, or 3 question of substance relating to the construction or application of the Constitution, or a treaty or statute. of the United States, which has not been, but should be, settled by this court; or where that court has not given proper efrect to an applicable decision of this court." 
not frequently, that application for the writ is made merely to secure delay. A lawyer who deliberately lends himself to such a purpose is guilty of conduct calling at least for the censure of the court, and he and his client may well incur a heavier penalty.

In most cases which the Supreme Court is given the power and discretion to review by certiorari, the new Act gives the judges of the lower court authority to certify relevant questions arising to the Supreme Court. This is another form of review, not granted the parties, but had at the option of the judges of the lower court. This method of review in the Supreme Court obtained under the prior law in cases in the Circuit Courts of Appeals and in the Court of Appeals of the District of Columbia. The addition to the cases now made subject to review in the Circuit Courts of Appeals may increase the frequency of the use of certification somewhat. Under the present Act, the Court of Claims, which could not do so before, may certify questions.

Under the new Act, the Supreme Court may ultimately review the judgments or decrees of all inferior courts created by Congress as fully as under previous legislation; but it can exercise under the new Act no direct and immediate review either by error, appeal, or certiorari over either the Supreme Court of the District of Columbia or its inferior Courts, the U. S. District Court of Alaska, the Supreme Court of Porto Rico, the United States District Court of Porto Rico, the Court of the Panama Canal Zone, the Circuit Court of the United States for China or the District Court for the Virgin Islands. Their judgments or decrees the Supreme Court can examine only after they have been first reviewed and passed upon by the Court of Appeals of the District of Columbia, or by the proper Circuit Court of Appeals, and then only by certiorari.

The courts whose judgments, decrees, orders and proceedings the Supreme Court may review directly are:

First. The nine Circuit Courts of Appeals and the Court of Appeals of the District of Columbia.

Second. The courts of last resort of the several states.

Third. The District Courts of the United States.

Fourth. The Court of Claims.

Fifth. The Supreme Court of the Philippine Islands.

Sixth. The Court of Customs Appeals.

Let us consider by what procedure this direct review may be had under each of these heads.

First. The general method of review of cases from the Cir. cuit Courts of Appeals or from the Court of Appeals of the District of Columbia by the Supreme Court is at the discretion of the Supreme Court by certiorari, or at the discretion of the Judges of the lower court by their certification to the Supreme Court of relevant questions arising in the case. The certiornri 
in such cases may be applied for before or after final judgment or decree; but if before, it must be applied for before submission of the cases to the lower court.

The only exception to this general rule is in a narrow class of cases in which the validity of a state statute is questioned as violating the Constitution or a treaty or statute of the United States, and the decision of the lower court is against its validity. In such a case, a writ of error or appeal from the intermediate appellate court lies to the Supreme Court, but the consideration of the reviewing court in such review is limited to the Federal question. Should the defeated party desire to have the whole case examined on its merits, he can only secure this by abandoning his right to an appeal or writ of error and by involing the discretion of the Supreme Court by applying for a writ of certiorari.

Second. In cases of final judgment or decree of a court of last resort of a state involving a federal question and thus permitting review by the Supreme Court of the United States, review can be had only in the discretion of the Supreme Court and by the granting of a certiorari, except in two classes of cases in which a writ of error lies. The first is where the validity under the Federal Constitution of a treaty or statute of the United States is questioned and the decision is against its validity; and the second is where the validity of a statute of a state under the Federal Constitution, treaty or law is questioned and the decision is in favor of its validity. There is no review provided for by certification of questions by the judges of the state court to the Supreme Court.

Third. There is no review of the judgments or orders of the District Courts of the United States by writ of certiorari from the Supreme Court. There are, however, three instances in which there is obligatory review by appeals from deciees of the District Courts, and one instance by writ of error to a judgment of the District Court. The appeals are-first from decrees in suits in equity brought by the United States to restrain violations of the Anti-Trust or Interstate Commerié Acts; second, from decrees in suits in equity brought teobtain interlocutory or final injunctions to prevent the enforcement of a statute of a state, or of an order made by an administrative Board or Commission of the "state; and, third, from decrees in suits in equity to enjoin enforcement of orders of the Interstate Commerce Commission other than for the payment of money. These three classes of appeals are distinguished by the fact that the orders or decrees to be appealed from can only be granted by what is called a three-judge court, a court which must have at least one Circuit Judge or Justice in its composition. The basis for these exceptions is that as the District Court is thus 
constituted of at least three judges who might constitute a Circuit Court of Appeals, it is to be ranked with that court in the weight to be given its conclusions. It perhaps might have been better in the interest of uniformity to have subjected these reviews to the test of an application for certiorari rather than to give them an obligatory character; but their special governmental or public importance prevailed to make them exceptions.

The only writ of error permitted from the Supreme Court to a District Court is in criminal cases in which the United States has been defeated by a ruling of the District Court, and where the defendant has not been exposed to jeopardy or acquitted by a verdict of the jury. The reason for this exception is doubtless in the need for expedition in securing a final construction of new criminal statutes by the court of last resort, so that the Government and those charged with violating the new law may have the earliest possible final interpretation of what the law means, and long trials and convictions, which might subsequently be set aside because of a faulty interpretation of the statute, may be avoided. Expedition and uniformity in construction are thus the controlling considerations.

In no other cases and in no other mode than as above stated is there any direct review of district courts by the Supreme Court. It can only be reached in other cases from those courts through the proper Circuit Court of Appeals by certiorari.

Fourth. All cases from the Court of Claims are to be reviewed by the Supreme Court by certiorari at the option of the Supreme Court, or by certificate of relevant questions by the Judges of the Court of Claims, and not otherwise.

Fifth. By this Act, any final judgment or decree of the Supreme Court of the Philippines, wherein the Constitution or any statute or treaty of the United States is involved, or where the value of any controversy exceeds $\$ 25,000$, may be reviewed only by certiorari from the Supreme Court of the United States, and there is no power in the Philippine Court to certify questions.

Sixth. By Section 195 of the Judicial Code, amended in 1914, 38 Stat. 703, ch. 267, final judgments or decrees in the Court of Customs Appeals may upon petition of either party in cases in which the construction of the Federal Constitution or a treaty is involved, or in other cases upon certificate of expediency by the Attorney General, be examined on certiorari by the Supreme Court. Cases in the Court of Customs Appeals are the only ones in the appellate jurisdiction of the Supreme Court not referred to and described in the new Act. The method of review in such cases is by certiorari, and there is no power given the Judges of the lower court to certify questions to the Supreme Court.

I have now recounted in the foregoing the entire appellate 
jurisdiction of the Supreme Court in review of the judgments of other courts. It does not of course include proceedings which in the docket of the Court are marked as original suits but which are incidental to its appellate jurisdiction. I refer to applications for writs of mandamus, quo warranto, prohibition and habeas corpus, which are directly brought in the Supreme Court, but are merely in aid of its appellate jurisdiction. The really original jurisdiction of the Supreme Court includes only eases affecting Ambassadors and other public ministers and consuls and those in which a state is a party, a jurisdiction which Congress may neither enlarge nor diminish, and which needs no congressional legislation to give it effect.

The number of cases of obligatory appellate jurisdiction conferred on the Supreme Court previous to the new Act, and which is now taken away by it, could be stated with fair approximation by a detailed classification of the cases heard and disposed of by the Court in the last three or four years, but I have not the records at hand to make such a statement. Without it, one can not be sure by how many cases the new Act will enable the Court to reduce its docket. A short resume of the classes of cases transferred from the Court's obligatory jurisdiction under the previous law to its certiorari jurisdiction under the new Act may give some general idea of its effect in this regard.

1st. Under the prior law, cases in the District Courts presenting questions of jurisdiction alone, involving the construction or application of the Federal Constitution or of a Federal treaty, prize cases, suits on claims against the United States for not exceeding $\$ 10,000$ under what is known as the Tucker Act, - could be directly carried to the Supreme Court by appeal. By the new Act all of these cases are now subject to review by the Circuit Courts of Appeals, and thence are reviewable only by certiorari or certificate in the Supreme Court.

2nd. The Judicial Code shows twenty-five classes of civil suits cognizable by the District Courts of the United States which if involving in value $\$ 1000$ are reviewable by the Circuit Court of Appeals. They embrace suits so rarely brought as to be regarded as nearly obsolete, as, for instance, suits arising under any law relating to the slave trade. On the other hand, they do include civil suits of more frequent occurrence. The more important of them are as follows:

1st, suits brought by the United States or by any officer thereof authorized by law to sue;

2nd, suits between citizens of the same state claiming lands under grants from different states;

3rd, suits arising under the Constitution or laws or treaties of the United States where more than $\$ 3,000$ is involved (presumably a considerable class). 
4th, seizures on land or waters not within admiralty or maritime jurisdiction.

5th, cases arising under the postal laws.

6th, suits and proceedings under any law regulating commerce, except such as may be governed by special statutes already mentioned.

7 th, civil suits and proceedings for enforcement of penalties and forfeitures incurred under any law of the United States.

8th, suits for damages by officers and persons for injury done them in protection or collection of the United States revenue or to enforce rights of citizens to vote.

9th, suits for damages by citizens injured in their federal constitutional rights.

10th, suits against consuls and vice-consuls.

11th, suits under immigration and contract labor laws.

12th, private suits under the Anti Trust Act.

13th, suits by Indians or part blood Indians for allotment under any law or treaty.

14th, suits by tenants in common or joint tenants for partition of land, in which the United States is also a tenant in common or joint tenant.

Under the prior law, such cases, if they involved more than $\$ 1000$ in amount, if not suits solely dependent upon the diverse citizenship of the parties for the Federal jurisdiction, or if not classed as arising under the patent, trade-mark, copyright, revenue, criminal or admiralty laws, were in the obligatory jurisdiction of the Supreme Court by writ of error to, or by appeal from, the Circuit Courts of Appeals. The effect of the new Act is to change all this jurisdiction from the obligatory to the certiorari and certificate class.

3rd. Under the prior law, cases from the Supreme Courts of Hawaii and Porto Rico presenting questions similar to those which were reviewable in the Supreme Court when removed from state courts of last resort, and in some constitutional and other cases from the District Court of Alaska, were embraced in the direct and obligatory appellate jurisdiction of the Supreme Court. These are now by the new Act first to be reviewed in the proper Circuit Courts of Appeals and then only can reach the Supreme Court by certiorari or certificate.

4th. Under the prior law, a final judgment or decree of a state court of last resort in a case in which is drawn in question an authority exercised under the United States, and in which the decision is against its validity, or where is drawn in question an authority exercised under a state, on the ground of its being repugnant to the Constitution, treaties or laws of the United States, and the decision is in favor of its validity, might be reexamined in the Supreme Court upon a writ of error. By the new Act these two classes of cases are removed from the obligatory to the certiorari jurisdiction, a change which makes 
for clarity, because the question whether a case presented an issue as to the validity of an authority under the United States or under a State, was not free from difficulty of determination.

5th. Under the prior law, decrees and judgments of the Court of Appeals of the District of Columbia in cases presenting questions of jurisdiction of the trial court, in prize cases, in cases involving application or construction of the Federal Constitution, the validity of any treaty or law of the United States, the validity of any State constitution or statute, the validity of any authority exercised under the United States, or the existence or scope of the power or duty of an officer of the United States, and in cases in which the construction of any statute of the United States was questioned, were reviewable by wit of error or appeal in the Supreme Court. By the new Act such eases are transferred from its obligatory appellate jurisdiction to that by certiorari or certificate.

6th. Under the prior law, all claims decided in the Court of Claims against the United States, of whatever amount, and all claims involving more than $\$ 3,000$, and decided against a claimant, were reviewable by appeal in the Supreme Court. All cases decided in the Court of Claims, of whatever amount, are put by the new Act in the certiorari and certificate classes.

7th. There were a few bankruptcy cases, appeals to the Supreme Court from other courts than the Circuit Courts of Appeals, under prior law which are brought by the new Act into the certiorari class.

This list, describing reviewable cases in the Supreme Court thus transferred from the obligatory to the discretionary class, is on its face a formidable one; but their actual number will not be so large as their description may suggest. It is to be noted of course that the addition to the certiorari class does not reduce pro tanto the cases to be considered on the merits by the Court. Experience shows that from fifteen to twenty per cent of applications for certiorari are granted. It remains to be seen whether eighty per cent of the cases transferred to the certiorari class by the new Act will be a sufficient reduction of its docket to enable the Court gradually to catch up with its work. We hope so.

The review of cases by certificate of questions to the Supreme Court has been somewhat increased by the new Act, but this is not likely to be burdensome because the exceptional cases in which it will be used would probably be admitted on certiorari, if not on certificate.

The opinion has been expressed that this new Act will so increase the business in the Circuit Courts of Appeals that additional judges in that Court may be necessary. Those courts have been successful in keeping abreast of their dockets, and it would 
be too bad to clog them in an effort to relieve the Supreme Court. I venture to doubt the fears expressed on this head.

The Act does add to the review by Circuit Courts of Appeals.

1st, That of interlocutory orders on motions to wind up a pending receivership or to take appropriate steps to accomplish the purposes thereof such as a sale or other disposal of property held thereunder.

2nd, Cases, already referred to, involving questions of jurisdiction of the District Courts, and those involving questions of Federal constitutional or treaty construction, which under the prior law could be carried by a short cut to the Supreme Court, but must now go to the Circuit Court of Appeals.

3rd, Cases of claims against the United States under the Tucker Act, which formerly went directly to the Supreme Court, but now go to the Circuit Courts of Appeals.

4th, The requirement that a Circuit and two District Judges shall as a three-judge district court hear applications for temporary injunctions to prevent enforcement of a state statute or the order of a State Board, has now been broadened so that the same number and kind of judges will have to pass on the final hearing in such cases. This will in effect increase the burden on judges of the Circuit Courts of Appeals.

In spite of all this, those courts have their dockets so well in hand that I think the increase, provided at the last Congress, of two Circuit Judges to malse six in the Eighth Circuit, a proposed and probable increase of one Circuit Judge to make four in the Second Circuit, and possibly one in the Sixth Circuit are all that are needed to enable the nine Circuit Courts of Appeals to continue to see their dockets cleared before each summer vacation.

By the new Act, applications for review of cases in all courts must be made in three months after final judgment, with the exception of that for certiorari in the Philippine Islands, for which six months is required. Theretofore six months was permitted in review of cases from the District Courts in Circuit Courts of Appeals. A justice of the Supreme Court may for good cause shown 'extend the time of applying for a certiorari in that Court sixty days.

The Act contains useful remedial provisions, as for instance that errors as to forms of review, whether by writ of error or appeals in all Federal Courts are to be disregarded, and a mistake in applying to the Supreme Court for review by writ of error from a state court of last resort when the application should have been for certiorari, may be treated as such. Another is that where the power to review either in the Circuit Courts of Appeals or the Supreme Court depends upon the value of the thing in controversy, and it is not disclosed, it may be shown by the oath of a party or other competent evidence. Another is that 
in a suit by or against any officers of the United States, or of the District of Columbia, or any territory or dependency, the cause may be continued and retained against the successor in office, if there be a substantial need for so continuing it; and the same provision is made where an action brought by or against an officer, a state or county, or a governmental ageney of the State is pending in a court of the United States, and the officer dies, or is separated from office. In that case the successor of such officer may be made a party after reasonable notice and an opportunity to make any objection which he may have.

Consideration of questions of jurisdiction in litigation in the Federal Courts is of primary importance to the practitioner. In every state court jurisdiction is a condition precedent to remedial action, but in courts of so-called general jurisdiction, like the courts of first instance of the States, their jurisdiction is usually so broad that little time is spent on questions of jurisdiction of the person or of the subject matter, if the parties are in court. In the Federal Courts it is not so. Their jurisdiction is something exceptional, carved out by the Federal Constitution and statutes of the sum total of judicial power of the States as it was before the Revolution, and favorable presumptions of its existence do not obtain in any direct proceeding of review. A complaining litigant in the Federal courts finds a constant challenge to his right to be there and must always be ready to point to the clause of the Federal Constitution and the statute by which he may rightly invoke the consideration of the court. This burden follows him clear through to the Supreme Court. Too often a counsel fails to appreciate that at once upon beginning his argument he must establish not only the jurisdiction of the court of first instance but the Supreme Court's jurisdiction of the particular appellate proceeding by which he is undertaking to reverse the lower court. The opening argument too often loses its force and sequence because of counsel's unreadiness to comply with the imperative insistence of the court in this regard. Excited and interested in the merits, he finds himself tangled with jurisdictional questions from the court which he has neglected in preparation. But even when he has done as much as he can do in this way, he has found difficulty in the language and structure of the Act of 1891 and its numerous amendments. It is to be hoped that the present Act is clearer and simpler.

I observe that one commentator on the new Act thinks it would have been better to have had a complete revision of the whole Judicial Code. Doubtless it would have been better, but such a revision without a corps of assistants, whose time should be exclusively devoted to it, would have been beyond the capacity of the Court with its regular duties to perform. The result now is 
that the new Act covers within its sections the entire appellate jurisdiction of the Supreme Court, with the exception of that of the Court of Customs Appeals contained in an amendment to a section of the Judicial Code. The new Act will certainly save to the practitioner a great deal of anxious search for recent and fugitive amendments of the appellate procedure.

Passage of the new Act has prompted the Court to revise and amplify its rules. No such thorough revision has ever been had in the history of the Court. The Committee which revised the Rules was the same Committee, with Mr. Justice Van Devanter at its head, which prepared the new Act. The Court is anxious that the Bar shall be as well advised as possible of the changes in the law and of the consequent changes in the Rules. A new pamphlet containing the Rules and the new Act has been printed, and can be had by practitioners upon application to the Clerk of the Supreme Court.

A question has been under consideration by the Court as to whether it would be practical to give oral hearings to applications for certioraris. The changes in the new Act will doubtless increase the number of these applications, and if the Court could be relieved by short oral statements of the burden of close examination of briefs and records, it might help its disposition of the business and at the same time give assurance to counsel of the fact, which seems sometimes to have been doubted, that the full Court seriously considers every application for a certiorari and votes upon it as a real issue to be judicially determined. If there are to be five hundred applications for certiorari a year (a conservative estimate), and ten minutes should be allowed to a side, this would consume, if all the applications were orally presented and opposed, eight weeks of the oral sessions of the Court. The Court gives about eighteen weeks to oral sessions during an annual term, so that it would take a little less than one-half of the oral sessions devoted by the Court to argument. Of course it is suggested that even if argument were permitted, advantage would not be taken in many cases in which briefs would be solely relied on. An experiment of a week or two at the beginning of the term might possibly enable the Court to judge more safely as to this. I fear, however, that the experiment would show to be true what Senator Cummins said upon the floor of the Senate, when it was proposed to require oral hearings of certiorari applications, that we might just as well not pass the law at all.

The Bar and the Court will await with very great interest the result of two years' operation under the Act. There are now so many cases on the docket which came up under the prior law that possibly a year should elapse before the real effect of the new law can be judged. 